\title{
CHANGES IN SOIL CHEMICAL PROPERTIES PROMOTED BY FERTIGATION WITH TREATED SANITARY WASTEWATER
}

Doi:http://dx.doi.org/10.1590/1809-4430-Eng.Agric.v37n2p343-352/2017

\section{SILVÂNIO R. SANTOS ${ }^{1 *}$, DANILO P. RIBEIRO ${ }^{2}$, ANTONIO T. MATOS $^{3}$, MARCOS K. KONDO ${ }^{4}$, EDCÁSSIO D. ARAÚJO ${ }^{5}$}

\footnotetext{
${ }^{1 *}$ Corresponding author. State University of Montes Claros (UNIMONTES)/ Janaúba - MG, Brazil.
}

E-mail: silvanio.santos@ unimontes.br

\begin{abstract}
We evaluate the application of treated sanitary wastewater (TSW) to provide potassium for crops and reduce demand for fresh water and mineral nutrients. The field experiment was arranged in randomized block design with four replications and five treatments: 50, 100, 150 and $200 \%$ of potassium requirements and a control with conventional fertilizer. The TSW was applied to maize (November 2012 to February 2013), cotton (June to November 2013) and bean (April to June 2014). After bean, soil chemical properties were evaluated until $0.8 \mathrm{~m}$ depth. Fertigation with TSW to potassium fertilization provided about $50 \%$ of water, nitrogen and phosphorus to the bean. The soil nutrient availability and soil organic matter did not increase, whereas sodium had linear increased with TSW levels in investigated soil depth. Soil pH showed same behavior that sodium, with the highest pH level of 6.5 in 0-0.2 m soil layer. Soil nutrients and organic matter did not increase with TSW doses up to $0.8 \mathrm{~m}$ depth. Soil $\mathrm{pH}$ and sodium had linear increasing with TSW doses, respectively up to 0.6 and $0.8 \mathrm{~m}$ soil depth. Fertigation with potassium recommendation also provided a high content of sodium, threatening the balance of soil-plant system with continuous use. The sodium should be the first reference to permanent wastewater reuse in agriculture.
\end{abstract}

KEYWORDS: effluent, fertilization, irrigation, sewage, sodium.

\section{INTRODUCTION}

In Brazil, water availability and quality are threatened in many watersheds, because of high demand for urban, industrial and agricultural uses, besides the released of sanitary wastewater into water bodies (BRASIL, 2013). The sanitary wastewater as a source of water and nutrients in agriculture is one of the best choices for dealing with the water crisis, keeping agriculture output and minimizing surface water contamination and environmental impacts. However, their use should be careful because of the soil salinity and sodicity risks, crop yield restriction, groundwater contamination, heavy metals, toxic and pathogenic load (QADIR et al., 2010).

In recent years, many investigations of wastewater reuse in agriculture were based on irrigation criteria, replacing full water requirements of crops with wastewater, resulting in problems like nitrogen losses by leaching (LEAL et al., 2010; BLUM et al., 2013) and increased soil salinity and sodicity, usually in short time (KIZILOGLU et al., 2008; VARALLO et al., 2012), with risks to soilplant system according to wastewater composition (MUYEN et al., 2011).

A better way to wastewater fertigation is the criteria of composition, balancing application rate with plant nutrition and soil fertility, reducing wastewater volume and expanding crop area with remaining water requirements supplied by other sources. Thus, investigation of composition criteria for long-term wastewater reuse, considering damage risk and soil buffering capacity are required. This study aimed to evaluate changes in soil chemical properties, after common bean with crop rotation and fertigation with treated sanitary wastewater, based on potassium requirements.

\footnotetext{
${ }^{2}$ Federal Institute of Northern Minas Gerais (IFNMG)/ Januária - MG, Brazil.

${ }^{3}$ Federal University of Minas Gerais (UFMG)/ Belo Horizonte - MG, Brazil.

${ }^{4}$ State University of Montes Claros (UNIMONTES)/ Janaúba - MG, Brazil.

${ }^{5}$ Master's degree student, Federal University of Viçosa (UFV)/ Viçosa - MG, Brazil. 


\section{MATERIAL AND METHODS}

The field experiment was developed in the Experimental Area of Companhia de Saneamento de Minas Gerais - COPASA, the sanitation company of Minas Gerais, Janaúba, Minas Gerais, Brazil (15 46' $12.6^{\prime}$ ' S, $43^{\circ} 19^{\prime} 13.5^{\prime}$ ' W, $530 \mathrm{~m}$ ), near the municipal sewage treatment plant (STP), of the same company. The STP have a preliminary treatment, followed by secondary treatment with upflow anaerobic sludge blanket reactor and tertiary treatment with a facultative pond and two maturation ponds in sequence and a discharge of treated sanitary wastewater (TSW) that was used in this experiment. In Janaúba city, the climate is tropical with dry winter and the soil is a Eutrophic Red Latosol (Oxisol) with sandy clay texture up to $0.60 \mathrm{~m}$ deep, and clay loam from 0.60 to $0.80 \mathrm{~m}$ (Table $1)$.

TABLE 1. Chemical and physical soil properties before treated sanitary wastewater disposal on maize.

\begin{tabular}{cccccccccccc}
\hline Soil depth & $\mathrm{pH}$ & $\mathrm{OM}$ & $\mathrm{P}$ & $\mathrm{K}$ & $\mathrm{Fe}$ & $\mathrm{Na}$ & $\mathrm{Ca}$ & $\mathrm{BS}$ & Sand & Silt & Clay \\
\hline $\mathrm{m}$ & \multicolumn{2}{c}{$\mathrm{g} \mathrm{kg}^{-1}$} & \multicolumn{1}{c}{$\mathrm{mg} \mathrm{dm}^{-3}-$} & & $-\mathrm{cmol}_{\mathrm{c}} \mathrm{dm}^{-3}-$ & $\%$ & - & $\mathrm{g} \mathrm{kg}^{-1}$ & \\
\hline $0.0-0.20$ & 6.6 & 15 & 3.5 & 138.8 & 17.9 & 0.13 & 3.5 & 76.4 & 517 & 222 & 261 \\
$0.20-0.40$ & 6.4 & 8.0 & 1.7 & 123.5 & 14.8 & 0.12 & 2.9 & 68.4 & 486 & 184 & 330 \\
$0.40-0.60$ & 6.1 & 5.0 & 1.4 & 77.8 & 15.1 & 0.12 & 2.8 & 62.8 & 441 & 192 & 367 \\
$0.60-0.80$ & 5.8 & 3.0 & 1.4 & 59.3 & 14.7 & 0.11 & 2.7 & 62.5 & 429 & 180 & 391 \\
\hline
\end{tabular}

OM: organic matter; BS: base Saturation.

The experimental trials evaluated the effects of fertigation with treated wastewater in the soil properties and crop yield in succession planting. The experimental plot area was cultivated with maize (November 2012 to February 2013), cotton (June to November 2013) and common bean (April to June 2014) with bean cultivars BRSMG Madrepérola and Ouro Negro in subplots.

Four potassium doses $(50,100,150$ and $200 \%$ of potassium dose recommendation) were supplied by treated sanitary wastewater. A control treatment (MF) was performed without treated sanitary wastewater, supplying $100 \%$ of potassium, nitrogen and phosphorus from conventional mineral fertilizer and irrigation with clean water (BRASIL, 2011).

A randomized block design with four replications and 20 experimental units were used, with the same treatments for the three crops. Plot size was $5.9 \mathrm{~m}$ long and $5.4 \mathrm{~m}$ wide, with one drip line beside each one of the six rows.

Bean sowing was made on 04/04/2014, and crop cycle started with $80 \%$ of minimum emergence, keeping plant stand of 12.8 plants $\mathrm{m}^{-2}$, equal to 277.778 plants ha ${ }^{-1}$. Plot harvest occurred 80 days after emergence.

The control treatment was fertilized with mineral sources $\left(100 \mathrm{~kg} \mathrm{ha}^{-1}\right.$ of $\mathrm{N}, 90 \mathrm{~kg} \mathrm{ha}^{-1}$ of $\mathrm{P}_{2} \mathrm{O}_{5}$ and $40 \mathrm{~kg} \mathrm{ha}^{-1}$ of $\mathrm{K}_{2} \mathrm{O}$ ), in five fertigations between 7 and 47 days after emergence. When nitrogen and phosphorus recommendation were not full supplied by wastewater, they were completed by fertigation with urea and purified mono-ammonium phosphate, on the same day of the control treatment fertigation.

All irrigation scheduling was performed every two days, using crop evapotranspiration (ETc), estimated by Hargreaves-Samani equation (ETo), crop coefficient $(\mathrm{Kc})$ and meteorological data from a portable weather station mounted in the experimental area (ALLEN et al., 2006). After the supply of TSW to provide the potassium levels, crop water demand was completed with the same clean water from control.

Analysis of the treated sanitary wastewater was performed monthly for determining chemical constituents, according to APHA (2012). These results were used on the next month to calculate treated sanitary wastewater dose for each treatment.

Soil samples were collected in the bean rows after harvest, in the layers 0-0.2, 0.2-0.4, 0.4-0.6 and 0.6-0.8 $\mathrm{m}$ to measure $\mathrm{pH}$ in water, soil organic matter, $\mathrm{P}, \mathrm{K}$, exchangeable $\mathrm{Na}, \mathrm{Ca}, \mathrm{Mg}, \mathrm{Fe}, \mathrm{Zn}$, 
$\mathrm{Mn}, \mathrm{B}, \mathrm{Cu}$ and soil potential acidity, according to DONAGEMA et al. (2011), obtaining the sum of bases, base saturation and potential cation exchange capacity.

In each soil layer, data was submitted to analysis of variance (ANOVA) and linear regression with SAEG 9.1. Regression models were chosen according to coefficients of significance, R-squared, and the ability to explain the phenomena studied. Regressions of potassium and phosphorus levels were not made because control treatment was fertilized with mineral sources, without zero nutrient level. So, we used the Dunnett test $(\mathrm{p}<0.05)$ to compare treated sanitary wastewater levels of these nutrients with control.

\section{RESULTS AND DISCUSSION}

In the autumn, between cotton harvested in November 2013 and the bean planting in April 2014, occurred $482 \mathrm{~mm}$ of rainfall. A very low rainfall over bean growth (Table 2) was expected due sowing in April, after the rainy season, resulting in total water demand provided by drip irrigation system, with TSW treatments providing 11 to $44.5 \%$ of irrigation.

TABLE 2. Treated sanitary wastewater (TSW) requirements, effective rainfall (rain), supplementary net irrigation depth (IR) and total irrigation depth (Total) applied to experimental plots during bean cycle.

\begin{tabular}{|c|c|c|c|c|}
\hline Treatment & TSW & Rain & IR & Total \\
\hline MF & 0.0 & 1.1 & 413.4 & 414.5 \\
\hline $50 \%$ & 46.1 & 1.1 & 367.3 & 414.5 \\
\hline $100 \%$ & 91.7 & 1.1 & 321.7 & 414.5 \\
\hline $150 \%$ & 137.8 & 1.1 & 275.6 & 414.5 \\
\hline $200 \%$ & 184.3 & 1.1 & 229.1 & 414.5 \\
\hline
\end{tabular}

MF: clean water irrigation and mineral fertilizer top-dressing with $40 \mathrm{~kg} \mathrm{ha}^{-1}$ of $\mathrm{K}_{2} \mathrm{O} ; 50$ to $200 \%$ of $\mathrm{K}_{2} \mathrm{O}$ recommendation for bean provided by TSW.

The low concentrations of micronutrients in treated sanitary wastewater were satisfactory to reuse, but sodium had a higher concentration than potassium (Table 3). The treated sanitary wastewater provided up to $200 \%$ of potassium recommendation for bean, with saving up $49.5 \%$ of $100 \mathrm{~kg} \mathrm{ha}^{-1}$ of nitrogen and $41 \%$ of $90 \mathrm{~kg} \mathrm{ha}^{-1}$ of phosphorus recommendations (Table 4). However, with $100 \%$ of potassium recommendation, just $31.1 \%$ of nitrogen and $20.7 \%$ of phosphorus were provided by treated sanitary wastewater.

During bean yield, 40.1 to $160.4 \mathrm{~kg} \mathrm{ha}^{-1}$ of sodium were applied by treated sanitary wastewater, matching with 50 to $200 \%$ of potassium recommendation. If we add sodium provided by wastewater in prior yields (maize and cotton), the plots received 203 to $795 \mathrm{~kg} \mathrm{ha}^{-1}$ of sodium with the same potassium levels.

The exchangeable sodium average in all soil layers fitted to the linear regression model, as a function of treated sanitary wastewater depth (Figure 1). The exchangeable sodium predicted by fitted equations were up to $0.306,0.348,0.364$ and $0.273 \mathrm{cmol}_{\mathrm{c}} \mathrm{dm}^{-3}$ from the surface to the deepest layer.

Considering previous levels of soil exchangeable sodium (Table 1), the soil profile accumulated $10.2,13.2,14.1$ and $9.4 \%$ to $0-0.2,0.2-0.4,0.4-0.6$ and $0.6-0.8 \mathrm{~m}$ depth, respectively, from the 795 $\mathrm{kg} \mathrm{ha}^{-1}$ of sodium provided by wastewater or $46.9 \%$ up to $0.8 \mathrm{~m}$ depth. Exchangeable sodium enrichment in the soil profile is common with wastewater irrigation to replenish total crop water demand (LEAL et al., 2009; SILVA et al., 2010; ZEMA et al., 2012; HENTATI et al., 2014). 
TABLE 3. Physicochemical characterization of treated sanitary wastewater provided to the bean.

\begin{tabular}{|c|c|c|c|c|c|}
\hline Variable & Average* & $\mathrm{SD}$ & Variable & Average* & SD \\
\hline $\mathrm{COD}\left(\mathrm{mg} \mathrm{L}^{-1}\right)$ & 166.5 & \pm 44.00 & $\mathrm{~B}\left(\mathrm{mg} \mathrm{L}^{-1}\right)$ & 0.03 & \pm 0.001 \\
\hline $\mathrm{N}_{\text {total }}\left(\mathrm{mg} \mathrm{L}^{-1}\right)$ & 50.50 & \pm 0.60 & $\mathrm{Fe}\left(\mathrm{mg} \mathrm{L}^{-1}\right)$ & 0.589 & \pm 0.058 \\
\hline $\mathrm{K}\left(\mathrm{mg} \mathrm{L}^{-1}\right)$ & 37.87 & \pm 1.773 & $\operatorname{Mn}\left(\mathrm{mg} \mathrm{L}^{-1}\right)$ & 0.10 & $\pm \quad 0.0$ \\
\hline $\mathrm{Na}\left(\mathrm{mg} \mathrm{L}^{-1}\right)$ & 87.51 & \pm 3.144 & $\mathrm{Zn}\left(\mathrm{mg} \mathrm{L}^{-1}\right)$ & 0.061 & \pm 0.019 \\
\hline $\mathrm{Ca}\left(\mathrm{mg} \mathrm{L}^{-1}\right)$ & 15.93 & \pm 0.97 & $\mathrm{Cu}\left(\mathrm{mg} \mathrm{L}^{-1}\right)$ & 0.007 & $\pm \quad 0.0$ \\
\hline $\operatorname{Mg}\left(\mathrm{mg} \mathrm{L}^{-1}\right)$ & 10.63 & 4.32 & $\mathrm{pH}$ & 7.60 & \pm 0.064 \\
\hline $\mathrm{P}\left(\mathrm{mg} \mathrm{L}^{-1}\right)$ & 8.82 & 0.73 & $\mathrm{EC}\left(\mathrm{dS} \mathrm{m}{ }^{-1}\right)$ & 1.093 & \pm 0.020 \\
\hline $\mathrm{Cl}\left(\mathrm{mg} \mathrm{L}^{-1}\right)$ & 137.1 & 5.56 & $\operatorname{RAS}\left(\mathrm{mmol}_{\mathrm{C}} \mathrm{L}^{-1}\right)^{0,5}$ & 4.165 & $-\quad-$ \\
\hline
\end{tabular}

*Monthly sampling average. Chemical oxygen demand (COD); Total nitrogen $\left(\mathrm{N}_{\text {total }}\right)$; Electrical conductivity of TSW (EC); Na adsorption ratio (SAR). Standard deviation (SD) equal to 0.00 are non-detection analysis used to minimum measure as result.

TABLE 4. Nutrients and sodium (Na) provided by mineral fertilization (MF) and treated sanitary wastewater (TSW) during the bean cycle.

\begin{tabular}{|c|c|c|c|c|c|c|c|c|c|c|c|c|}
\hline \multicolumn{13}{|c|}{ Nutrient / element added to soil $\left(\mathrm{kg} \mathrm{ha}^{-1}\right)$} \\
\hline \multirow{2}{*}{ Treat. } & \multicolumn{3}{|c|}{$\mathrm{N}^{*}-$} & \multicolumn{3}{|c|}{$-\mathrm{P}_{2} \mathrm{O}_{5}-$} & \multicolumn{3}{|c|}{$-\mathrm{K}_{2} \mathrm{O}-$} & \multicolumn{3}{|c|}{$-\mathrm{Na}-$} \\
\hline & MF & TSW & Total & $\mathrm{MF}$ & TSW & Total & MF & TSW & Total & MF & TSW & Total \\
\hline $\mathrm{MF}$ & 100.0 & 0.0 & 100.0 & 90.0 & 0.0 & 90.0 & 40.0 & 0.0 & 40.0 & 0.0 & 0.0 & 0.0 \\
\hline $50 \%$ & 78.0 & 22.1 & 100.1 & 81.0 & 9.3 & 90.3 & 0.0 & 20.1 & 20.1 & 0.0 & 40.1 & 40.1 \\
\hline $100 \%$ & 69.0 & 31.1 & 100.1 & 71.0 & 18.6 & 89.6 & 0.0 & 39.8 & 39.8 & 0.0 & 79.8 & 79.8 \\
\hline $150 \%$ & 62.0 & 40.3 & 102.3 & 62.0 & 27.9 & 89.9 & 0.0 & 59.9 & 59.9 & 0.0 & 119.9 & 119.9 \\
\hline $200 \%$ & 61.0 & 49.5 & 110.5 & 52.0 & 37.3 & 89.3 & 0.0 & 80.1 & 80.1 & 0.0 & 160.4 & 160.4 \\
\hline
\end{tabular}

$* \mathrm{~N}$ available to plants; Treat. treatment; MF: clean water irrigation and $40 \mathrm{~kg} \mathrm{ha}^{-1}$ of $\mathrm{K}_{2} \mathrm{O}$ as mineral fertilizer; 50 to $200 \%$ of $\mathrm{K}_{2} \mathrm{O}$ recommendation for bean supplied by TSW.

There was no change in exchangeable calcium (Ca) up to $0.60 \mathrm{~m}$ depth (Figure 1). In the deepest layer, calcium decrease with treated sanitary wastewater depth, related to calcium leaching after displaced by sodium from negative charges of soil colloids. Magnesium did not differ between treatments to all soil layers. The average magnesium was $1.41,1.2,0.85$ and $0.8 \mathrm{cmol}_{\mathrm{c}} \mathrm{dm}^{-3}$ to 0.0 $0.2,0.2-0.4,0.4-0.6$ and $0.6-0.8 \mathrm{~m}$ depth, respectively.

The alkaline $\mathrm{pH}$ of treated sanitary wastewater (Table 3 ) linear changed soil $\mathrm{pH}$ up to $0.60 \mathrm{depth}$ (Figure 1), without effect in the deepest layer. Organic matter decomposition can decrease soil $\mathrm{pH}$ because of organic acids formation in the first stage of anaerobic phase decomposition (MATOS, 2014), similar to irrigation with raw wastewater (KIZILOGLU et al., 2008; SANTOS et al., 2015). However, with time, continuous release of organic waste promotes soil $\mathrm{pH}$ increase due to the base cations from organic matter mineralization (GALVÃO et al., 2008). 

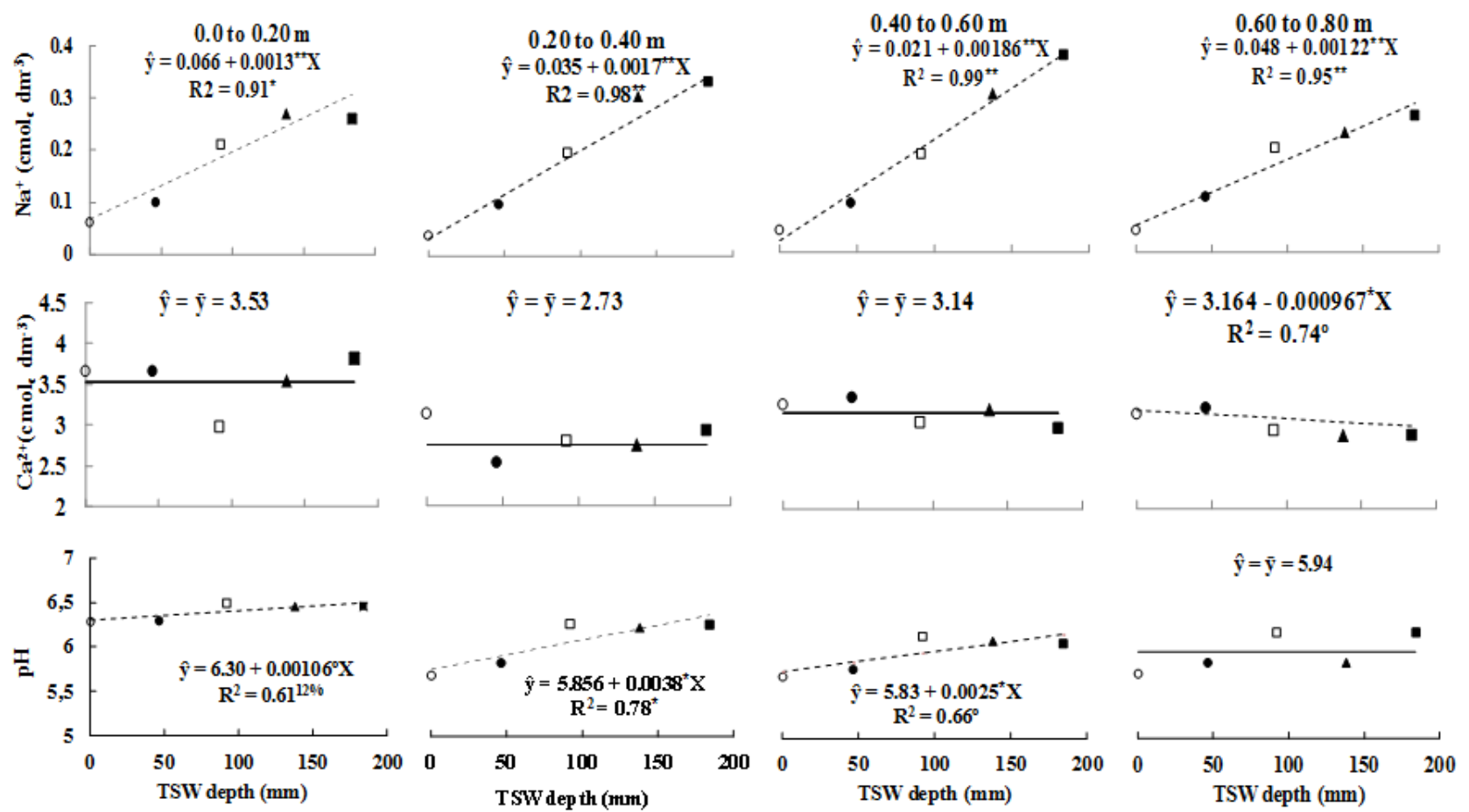

FIGURE 1. Average content of exchangeable $\mathrm{Na}, \mathrm{Ca}$ and $\mathrm{pH}$ in the soil layers after bean with different sources and levels of potassium doses $\left(40 \mathrm{~kg} \mathrm{ha}^{-1}\right.$ of $\left.\mathrm{K}_{2} \mathrm{O}=100 \%\right)$. $\circ$ Mineral fertilizer, $\bullet 50$, $\square$ $100, \boldsymbol{\Delta} 150$ and $\mathbf{- 2 0 0 \%}$ of $\mathrm{K}_{2} \mathrm{O}$ recommendation for bean supplied by treated sanitary wastewater (TSW). Significant at $(* *) 0.01$ and $(*) 0.05$ level by the t-test. Significant at $\left(^{\circ}\right) 0.10$ level or less to $\left(\mathrm{R}^{2}\right)$ model by the F-test.

Wastewater application change soil $\mathrm{pH}$ close to wastewater $\mathrm{pH}$ (XU et al., 2010), which can be amphoteric properties (PEREIRA et al., 2011). Thus, continuous release of wastewater can increase soil pH (PEREIRA et al., 2011; REZAPOUR \& SAMADI 2011; HENTATI et al., 2014;) or decrease (XU et al., 2010; ZEMA et al., 2012; HIDRI et al., 2014;), to approach the wastewater pH.

Soil organic matter content did not change between treatments, with the average of 11.7, 4.3 and $3.8 \mathrm{~g} \mathrm{~kg}^{-1}$ to $0-0.2,0.2-0.6$ and $0.6-0.8 \mathrm{~m}$ depth, respectively. Notice decreasing of soil organic matter related to content before wastewater disposal (Table 1). Considering Minas Gerais standards (ALVAREZ V. et al., 1999), organic matter was low in soil surface and very low in 0.2 to $0.8 \mathrm{~m}$ depth, even with uninterrupted treated sanitary wastewater application in successive crops. Therefore, it is recommended organic matter addition to soil.

Although wastewater is a source of organic compounds, only after several years of continuous application it has been observed its increase (XU et al., 2010), without changing in the short-term application (SILVA et al., 2015). The long-term increase of organic carbon can be in surface soil layer after 15 years of disposal (HIDRI et al., 2014) or 0.2 to $0.4 \mathrm{~m}$ soil layer after 15 and 20 years (HENTATI et al., 2014) and 13 to $44 \%$ increase after 40 years of raw wastewater disposal (RAZAPOUR \& SAMADI, 2011). Thus, the agricultural reuse of treated or untreated sanitary sewage does not replace organic fertilizers, considering the low increments of soil organic matter, even with the long-term application. Agricultural wastewater reuses combined with organic fertilizers are soil conditioners, improving crop nutrition, growth, and yield (SILVA et al., 2013; MASCIANDARO et al., 2014).

Organic matter contributes to soil aggregate stability, improving macroporosity and hydraulic conductivity (WANG et al., 2014) with minor risks of clay dispersion caused by sodium in soil (MUYEN et al., 2011). Increments of organic matter in surface layers are important to soil structure and heavy metals immobilization, protecting against metal uptake by plants. Therefore, areas with treated sanitary wastewater disposal must be fertilized with organic matter (BARRETOS et al., 2013).

Available potassium and phosphorus were not submitted to regression analysis because mineral fertilizer was used in the control, so, there was no treatment with zero nutrient level. Dunnett's test 
was used to compare soil nutrients listed in Table 5. It was expected that available phosphorus was constant between treatments because we calculate the same dose for all treatments (Table 4).

Wastewater disposal increased available phosphorus in all soil layers after bean yield, because applying high nutrient doses to balance the low soil phosphorus level, according to the Brazilian fertilizing standards that define fertilizing doses above crops requirements to compensate soil phosphorus adsorption in weathering soils.

The average content of available potassium was lower than control only in 0.2 to $0.4 \mathrm{~m}$ of soil depth with $150 \%$ of nutrient recommendation supplied by treated sanitary wastewater. No differences were observed in the other soil layers. Thus, treated sanitary wastewater application to supply up to $200 \%$ of potassium recommendation did not improve this nutrient in the soil.

A decrease of available soil potassium was mainly observed in wastewater treatments, compared to start condition (Table 1). Low available potassium after two years of treated sanitary wastewater disposal, reported by PEREIRA et al. (2011) and ZEMA et al. (2012) may be related to improved root system of crops. The high soil fertility resulting from nutrient-rich wastewater improved nutrients availability and uptake by plants (FONSECA et al., 2007). However, increases of exchangeable sodium in soil profile can reduce exchangeable potassium by replacing it in cation exchange complex and loss by leaching to deeper layers (PEREIRA et al., 2011). In this case, the high sodium concentration promotes phytotoxicity and suppression of potassium uptake.

TABLE 5. Analysis of variance and Dunnett's test for K and P levels in the soil layers after bean with different sources and levels of potassium fertilization.

\begin{tabular}{|c|c|c|c|c|c|c|c|c|}
\hline & \multicolumn{4}{|c|}{$-\mathrm{K} \longrightarrow$} & \multicolumn{4}{|c|}{$\longrightarrow \mathrm{P}$} \\
\hline Depth (m) & $0.0-0.2$ & $0.2-0.4$ & $0.4-0.6$ & $0.6-0.8$ & $0.0-0.2$ & $0.2-0.4$ & $0.4-0.6$ & $0.6-0.8$ \\
\hline Significance & ns & $*$ & $*$ & ns & ns & ns & ns & ns \\
\hline $\mathrm{CV}(\%)$ & 21.1 & 17.5 & 27.8 & 38.2 & 32.2 & 38.1 & 67.5 & 70.1 \\
\hline Treatment & & & & $\mathrm{mg}$ & $\mathrm{Im}^{-3}$ & & & \\
\hline MF & 131.9 & 91.61 & 67.57 & 53.6 & 25.57 & 9.3 & 5.98 & 4.29 \\
\hline $50 \%$ & 117.9 & 73.41 & 72.44 & 54.57 & 32.04 & 6.84 & 3.38 & 4.4 \\
\hline $100 \%$ & 108.5 & 88.03 & 81.21 & 44.83 & 25.66 & 7.09 & 2.91 & 3.04 \\
\hline $150 \%$ & 90.96 & $56.52 \mathrm{a}$ & 37.68 & 48.4 & 24.27 & 9.1 & 3.09 & 5.48 \\
\hline $200 \%$ & 110.1 & 85.11 & 63.67 & 44.5 & 22.22 & 7.23 & 4.87 & 3.34 \\
\hline Average & 111.9 & 75.8 & 64.5 & 49.2 & 25.9 & 7.6 & 4.05 & 4.11 \\
\hline
\end{tabular}

Significant at $(*) 0.05$ and (ns) non-significant by the F-test; MF: clean water irrigation and $40 \mathrm{~kg} \mathrm{ha}^{-1}$ of $\mathrm{K}_{2} \mathrm{O}$ as mineral fertilizer top-dressing; 50 to $200 \%$ of $\mathrm{K}_{2} \mathrm{O}$ recommendation for bean provided by TSW; Treatments with "a" letter are significantly different from the control (MF, $\alpha=0.05$ ) in the same column using a Dunnett's comparison.

After bean, no differences were observed between soil layers to values of potential acidity, sum of bases, potential cation exchange capacity and base saturation. Furthermore, in the surface layer, exchangeable $\mathrm{Ca}$ and $\mathrm{Mg}$ influenced the sum of bases, $\mathrm{CEC}_{7}$, and base saturation. Considering Minas Gerais standards (ALVAREZ V. et al., 1999), the average sum of bases (5.15, 4.19, 4.21 and 3.96 $\mathrm{cmol}_{\mathrm{c}} \mathrm{dm}^{-3}$ from surface to deepest layer, respectively) and average base saturation in the same layers $(72.7 \%, 68.5 \%, 67.5 \%$ and $66.5 \%)$ were optimum level, and potential cation exchange capacity (6.97, $6.08,6.17$ and $5.92 \mathrm{cmol}_{\mathrm{c}} \mathrm{dm}^{-3}$ ) were medium level.

The average potential acidity was low in soil layers $\left(1.82,1.90,1.97\right.$, and $\left.1.95 \mathrm{cmol}_{\mathrm{c}} \mathrm{dm}^{-3}\right)$. The potential soil acidity may decrease by treated sanitary wastewater disposal, reaching zero effect in the soil after one year of application replacing $150 \%$ of water requirements for the orange tree. The alkaline $\mathrm{pH}$ of treated sanitary wastewater result from a high level of $\mathrm{HCO}_{3}{ }^{-}$and exchangeable bases, that replaces $\mathrm{Al}^{3+}$ and $\mathrm{H}^{+}$on soil colloids (PEREIRA et al., 2011). However, this study showed that treated sanitary wastewater application below $50 \%$ of crop water requirements does not change the potential soil acidity. 
Treatment levels have no influence on available $\mathrm{Zn}$ and $\mathrm{B}$ in soil layers. The averages $\mathrm{Zn}$ were $1.27,0.42,0.55$ and $0.17 \mathrm{mg} \mathrm{dm}^{-3}$; averages $B$ were $0.26,0.23,0.25$ and $0.35 \mathrm{mg} \mathrm{dm}^{-3}$, both to $0.0-0.2,0.2-0.4,0.4-0.6$ and $0.6-0.8 \mathrm{~m}$ depth, respectively. The Fe, only in the surface layer, fitted to linear regression with treated sanitary wastewater irrigation depth (Figure 2). Available Mn in 0.4 to $0.6 \mathrm{~m}$ soil depth fitted to the quadratic regression model, with upward trend above $100 \%$ of $\mathrm{K}_{2} \mathrm{O}$ recommendation supplied by treated sanitary wastewater. Below $0.2 \mathrm{~m}$ soil depth, available copper showed a downward linear trend with treated sanitary wastewater irrigation depth.
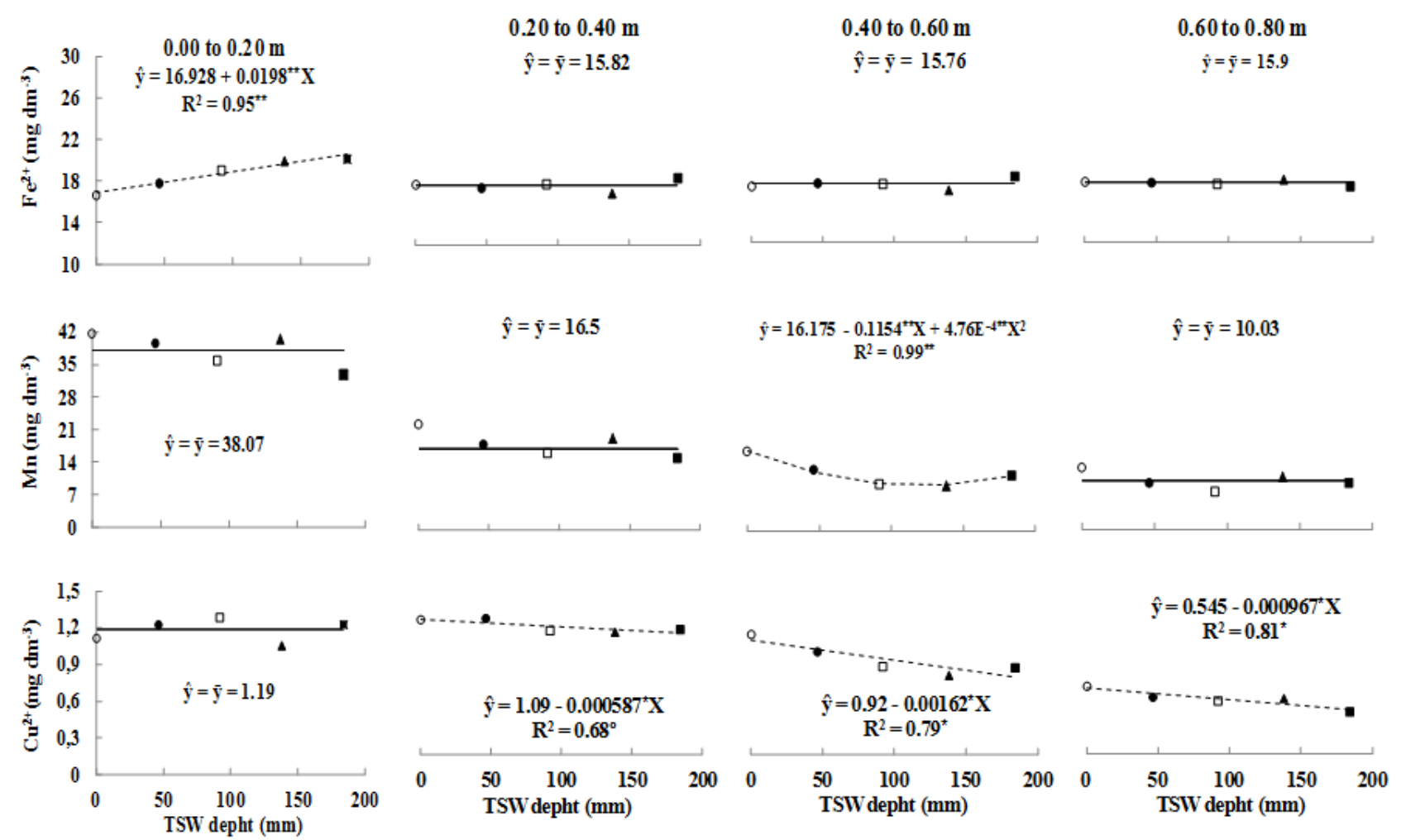

FIGURE 2. Average content of micronutrients, $\mathrm{Fe}, \mathrm{Mn}$ and $\mathrm{Cu}$ available in the soil layers after bean with different sources and levels of $\mathrm{K}$ top-dressing $\left(40 \mathrm{~kg} \mathrm{ha}^{-1}\right.$ of $\left.\mathrm{K}_{2} \mathrm{O}=100 \%\right)$. ० Mineral fertilizer, $\bullet 50, \square 100, \boldsymbol{\Lambda} 150$ and $\boldsymbol{\square} 200 \%$ of $\mathrm{K}_{2} \mathrm{O}$ recommendation for bean supplied by treated sanitary wastewater (TSW). Significant at $(* *) 0.01$ and $(*) 0.05$ level by the t-test. Significant at $\left({ }^{\circ}\right) 0.10$ level or less to $\left(\mathrm{R}^{2}\right)$ model by the F-test.

Most of the available micronutrients in soil are middle to very low level, except Mn, truly high up to $0.4 \mathrm{~m}$ and good layers below (ALVAREZ V. et al., 1999). Improved micronutrient levels in soil could limit plant growth and subsequently treated sanitary wastewater application. On the other hand, we can see the future necessity of additional micronutrient fertilizer in next crop.

Cation leachate in sandy clay soil, with low organic matter, limited available heavy metals until three years of treated sanitary wastewater disposal, however, heavy metals increase after eight years of continuous disposal (XU et al., 2010).

The bean irrigation with treated sanitary wastewater and water source criteria increase levels of soil electrical conductivity, $\mathrm{N}$, exchangeable $\mathrm{K}, \mathrm{P}, \mathrm{Fe}, \mathrm{Cu}, \mathrm{Zn}, \mathrm{Mn}$ and available $\mathrm{Ni}$ in the soil, also increasing nutrient concentrations in plant tissue, however, below reference limits (SAFFARI \& SAFFARI, 2013).

Sandy soil after two years of treated sanitary wastewater irrigation have a continuous increase of $\mathrm{Cu}, \mathrm{Ni}$ and $\mathrm{Cd}$, but still remaining under tolerable limits (HIDRI et al., 2014). Same situation found by HENTATI et al. (2014) with increasing of $\mathrm{Mn}, \mathrm{Fe}, \mathrm{Ni}, \mathrm{Co}, \mathrm{Cu}$ and $\mathrm{Pb}$ contents in the soil after 15 to 20 years of treated sanitary wastewater disposal without exceeding the tolerable limits. Thus, despite the increase of micronutrients and heavy metals to be ordinary in soils after treated sanitary wastewater irrigation to restore crop water need, levels usually remain within tolerable limits. 


\section{CONCLUSIONS}

1. Soil nutrients and organic matter do not increase with treated sanitary wastewater doses up to $0.8 \mathrm{~m}$ depth.

2. Soil $\mathrm{pH}$ and exchangeable sodium have linear increasing with treated sanitary wastewater doses, respectively up to 0.6 and $0.8 \mathrm{~m}$ soil depth.

3. Fertigation limited by potassium recommendation for crops provided together with the high content of sodium, threatening the balance of soil-plant system with continuous use.

4. Sodium should be the first reference element to continuous wastewater reuse in agriculture.

\section{ACKNOWLEDGMENTS}

The authors wish to acknowledge the Companhia de Saneamento de Minas Gerais - COPASA, the sanitation company of Minas Gerais and Fundação de Amparo à Pesquisa do Estado de Minas Gerais - FAPEMIG, the Minas Gerais State research foundation, for financial support and providing grants.

\section{REFERENCES}

ALLEN, R.G.; PEREIRA, L.S.; RAES, D.; SMITH, M. Crop Evapotranspiration. Guidelines for computing crop water requirements. Rome: FAO, 2006. 320 p. (Irrigation and Drainage, 56).

ALVAREZ V., V.H.; NOVAIS, R.F.; BARROS, N.F.; CANTARUTTI, R.B.; LOPES, A.S. Interpretação dos resultados de análises de solos. In: RIBEIRO, A.C.; GUIMARÃES, P.T.G.; ALVAREZ V., V.H. (Ed.). Recomendações para o uso de corretivos e fertilizantes em Minas Gerais (5 aproximação). Viçosa: UFV, 1999. p. 25-36.

APHA - AMERICAN PUBLIC HEALTH ASSOCIATION; AWWA - AMERICAN WATER WORKS ASSOCIATION; WEF - WATER ENVIRONMENT FEDERATION. Standard methods for the examination of water and wastewater. 22th ed. Washington: APHA/AWWA/WEF, 2012. $1360 \mathrm{p}$.

BARRETO, AURELIR N.; NASCIMENTO, J.J.V.R.; MEDEIROS, E.P.; NÓBREGA, J.A.; BEZERRA, J.R.C. Changes in chemical attributes of a Fluvent cultivated with castor bean and irrigated with wastewater. Revista Brasileira de Engenharia Agrícola e Ambiental, Campina Grande, v. 17, n. 5, p. 480-86, maio, 2013. Disponível em: < http://www.scielo.br/pdf/rbeaa/v17n5/a03v17n5.pdf>. Acesso em: 25 out. 2015.

BLUM, J. MELFI, A.J.; MONTES, C.R.; GOMES, T.M. Nitrogen and phosphorus leaching in a tropical Brazilian soil cropped with sugarcane and irrigated with treated sewage effluent. Agricultural Water Management, Amsterdam, v. 117, n. 1, p. 115-22, jan. 2013. doi: 10.1016/j.agwat.2012.11.010

ANA - AGÊNCIA NACIONAL DE ÁGUAS. Relatório de conjuntura dos recursos hídricos no Brasil - 2013. Brasília, DF: ANA/SPR, 2013. 432 p. Disponível em:

$<$ http://arquivos.ana.gov.br/institucional/spr/conjuntura/webSite_relatorioConjuntura/projeto/index. html>. Acesso em: 25 oct. 2015.

BRASIL. Ministério da Saúde. Portaria n. 2.914 de Dezembro de 2011. Dispõe sobre os procedimentos de controle e de vigilância da qualidade da água para consumo humano e seu padrão de potabilidade; 2011. Brasilia, DF: Ministério da Saúde; 2011. Disponível em:<http://bvsms.saude. gov.br/bvs/saudelegis/gm/2011/prt2914_12_12_2011.html>. Acesso em: 25 ago. 2015.

DONAGEMA, G.K.; CAMPOS, D.V.B. de; CALDERANO, S.B.; TEIXEIRA, W.G.; VIANA, J. H.M. (Org.). Manual de métodos de análises de solos. 2 ed. rev. Rio de Janeiro: Embrapa Solos, 2011.230 p. 
FONSECA, A.F.; HERPIN, U; PAULA, A.M.; VICTORIA, R.L.; MELFI, A.J. Agricultural use of treated sewage effluents: Agronomic and environmental implications and perspectives for Brazil. Scientia Agricola, Piracicaba, v. 64, n.2, p.194-209, mar./abr. 2007. Disponível em: < http://www.scielo.br/pdf/sa/v64n2/a14v64n2.pdf > . doi: 10.1590/S0103-90162007000200014.

GALVÃO, S.R.S.; SALCEDO, I.H.; OLIVEIRA, F.F. Acumulação de nutrientes em solos arenosos adubados com esterco bovino. Pesquisa Agropecuária Brasileira, Brasília, DF, v.43, n.1, p. 99105, jan. 2008. Disponível em: <http://www.scielo.br/pdf/pab/v43n1/a13v43n1.pdf >. Acesso em: October, 25, 2015.

HENTATI, O.; CHAKER, S.; WALI, A.; AYOUB, T.; KSIBI, M. Effects of long-term irrigation with treated wastewater on soil quality, soil-borne pathogens, and living organisms: case study of the vicinity of El Hajeb (Tunisia). Environmental Monitoring and Assessment, Dordrech, v. 186, n. 5, p. 2671-83, maio, 2014. doi: 10.1007/s10661-013-3570-z

HIDRI, Y.; FOURTI, O.; ETURKI, S.; JEDIDI, N.; CHAREF, A.; HASSEN, A. Effects of 15-year application of municipal wastewater on microbial biomass, fecal pollution indicators, and heavy metals in a Tunisian calcareous soil. Journal of Soils and Sediments, Landsberg, v. 14, n. 1, p. 155-63, jan. 2014. doi: 10.1007/s11368-013-0801-4

KIZILOGLU, F.M.; TURAN, M.; SAHIN, U.; KUSLU, Y.; DURSUN, A. Effect of untreated and treated wastewater irrigation on some chemical properties of cauliflower (Brassica oleracea $\mathrm{L}$. var. botrytis) and red cabbage (Brassica oleracea L. var. rubra) grown on calcareous soil in Turkey. Agricultural Water Management, Amsterdam, v. 95, n. 6, p. 716-24, jun. 2008. doi: 10.1016/j.agwat.2008.01.008

LEAL, R.M.P.; MONTES, C.R.; DA FONSECA, A.F.; FIRME, L.P.; HERPIN, U.; DIAS, C.T.S.; MELFI, A.J. Carbon and nitrogen cycling in a tropical Brazilian soil cropped with sugarcane and irrigated with wastewater. Agricultural Water Management, Amsterdam, v. 97, n. 2, p. 271-76, feb. 2010. doi: 10.1016/j.agwat.2009.09.018

LEAL, R.M.P.; HERPIN, U.; FONSECA, A.F.; FIRME, L.P.; MONTES, C.R.; MELFI, A.J. Sodicity and salinity in a Brazilian Oxisol cultivated with sugarcane irrigated with wastewater. Agricultural Water Management, Amsterdam, v. 96, n. 2, p. 307-16, feb. 2009. doi: 10.1016/j.agwat.2008.08.009

MASCIANDARO, G.; PERUZZI, E.; DONI, S.; MACCI, C. Fertigation with Wastewater and Vermicompost: Soil Biochemical and Agronomic Implications. Pedosphere, Beijing, v. 24, n. 5, p. 625-34, oct. 2014. doi: 10.1016/S1002-0160(14)60048-5

MUYEN, Z.; MOORE, G.A.; WRIGLEY. R.J. Soil salinity and sodicity effects of wastewater irrigation in South East Australia. Agricultural Water Management, Amsterdam, v.99, n. 1, p. 33-41, nov. 2011. doi: 10.1016/j.agwat.2011.07.021

PEREIRA, B.F.F.; HE, Z.L.; SILVA, M.S.; HERPIN, U.; NOGUEIRA, S.F.; MONTES, C.R.; MELFI, A.J. Reclaimed wastewater: impact on soil-plant system under tropical conditions. Journal of Hazardous Materials, Amsterdam, v. 192, n. 1, p. 54-61, aug. 2011. doi:

10.1016/j.jhazmat.2011.04.095

QADIR, M.; WICHELNS, D.; RASCHID-SALLY, L.; MCCORNICK, P.G.; DRECHSEL, P.; BAHRI, A.; MINHAS, P.S. The challenges of wastewater irrigation in developing countries. Agricultural Water Management, Amsterdam, v. 97, n. 4, p. 561-68. apr. 2010. doi: 10.1016/j.agwat.2008.11.004

REZAPOUR, S; SAMADI, A. Soil quality response to long-term wastewater irrigation in Inceptisols from a semi-arid environment. Nutrient Cycling in Agroecosystems, Dordrech, v. 91, n. 3, p. 269-80, dec. 2011. doi: 10.1007/s 10705-011-9460-2 
SAFFARI, V.R.; SAFFARI, M. Effect of treated municipal wastewater on bean growth, soil chemical properties, and chemical fractions of zinc and copper. Arabian Journal of Geosciences, Berlin, v. 6, n. 11, p. 4475-85, nov. 2013. doi: 10.1007/s12517-012-0690-7

SANTOS, S.R. ; KONDO, M.K. ; OLIVEIRA, P.M. de ; ANDRADE JUNIOR, I.O. ; MATOS, A. T. Short-term changes in soil properties due to sanitary wastewater irrigation as a potassium source. Australian Journal of Crop Science, v. 9, n. 8, p. 713-20, aug. 2015. Disponível em:< http://www.cropj.com/kondo_9_8_2015_713_720.pdf >. Acesso em: 25 out. 2015.

SILVA, D.F.; MATOS, A.T.; PEREIRA, O.G.; CECON, P.R.; MOREIRA, D.A. Disponibilidade de sódio em solo com capim tifton e aplicação de percolado de resíduo sólido. Revista Brasileira de Engenharia Agrícola e Ambiental, Campina Grande, v. 14, n. 10, p. 1094-100, out. 2010. Disponível em:<http://www.scielo.br/pdf/rbeaa/v14n10/v14n10a11.pdf >. doi: 10.1590/S141543662010001000011

SILVA, L.V.B.D.; LIMA, V.L.A.; SILVA, V.N.B.; SOFIATTI, V.; PEREIRA, T.L.P. Torta de mamona residual e irrigação com efluente sobre crescimento e produção de algodoeiro herbáceo.

Revista Brasileira de Engenharia Agrícola e Ambiental, Campina Grande, v. 17, n. 12, p. 126470, dez. 2013. Disponível em:< http://www.scielo.br/pdf/rbeaa/v17n12/v17n12a03.pdf >. doi: $10.1590 / \mathrm{S} 1415-43662013001200003$

SILVA, A.A.; LANA, A.M. Q.; LANA, R.M.M. Q.; COSTA, A.M. Fertilização com dejetos suínos: influência nas características bromatológicas da Brachiaria decumbens e alterações no solo. Engenharia Agrícola, Jaboticabal, v. 35, n. 02, p. 254-65, mar./abr. 2015. Disponível em:< http://www.scielo.br/pdf/eagri/v35n2/1809-4430-eagri-35-2-0254.pdf>. doi: 10.1590/1809-4430

VARALLO, A.C.T.; SOUZA, C.F.; SANTORO, B.L. Mudanças nas características físico-químicas de um Latossolo Vermelho-Amarelo distrófico após a irrigação com água de reúso na cultura da alface-crespa (Lactuca sativa, L.). Engenharia Agrícola, Jaboticabal, v. 32, n. 2, p. 271-79, mar./abr. 2012. Disponível em: <http://www.scielo.br/pdf/eagri/v32n2/a07v32n2.pdf>. doi: 10.1590/S0100-69162012000200007

WANG, L.; SUN, X.; LI, S.; ZHANG, T.; ZHANG, W.; ZHA, P. Application of Organic Amendments to a Coastal Saline Soil in North China: Effects on Soil Physical and Chemical Properties and Tree Growth. PLoS ONE, San Francisco, v. 9, n. 2, e89185, feb. 2014. Disponível em: < http://journals.plos.org/plosone/article?id=10.1371/journal.pone.0089185>. doi: 10.1371/journal.pone.0089185

XU, J.; WU, L.; CHANG, A.C.; ZHANG, Y. Impact of long-term reclaimed wastewater irrigation on agricultural soils: a preliminary assessment. Journal of Hazardous Materials, Amsterdam, v. 183, n. 1-3, p. 780-786, nov. 2010. doi: 10.1016/j.jhazmat.2010.07.094

ZEMA, D.A.; BOMBINO, G.; ANDILORO, S.; ZIMBONE, S. M. Irrigation of energy crops with urban wastewater: Effects on biomass yields, soils and heating values. Agricultural Water Management, Amsterdam, v. 115, n. 1, p. 55-65, dec. 2012. doi: 10.1016/j.agwat.2012.08.009 